Reviu Akuntansi dan Bisnis Indonesia, Vol. 2 No. 2, Hlm: 97-106, Desember 2018

Website: http://journal.umy.ac.id/index.php/rab

\title{
Pengaruh Profitabilitas, Ukuran Perusahaan, Leverage, Afiliasi Politik, Dan Dewan Komisaris Independen Terhadap Carbon Emission Disclosure : Studi Empiris pada Perusahaan Pertambangan yang Terdaftar di BEI Periode 2014-2016
}

\author{
Hannifah Nur Farida; Hafiez Sofyani \\ Program Studi Akuntansi Univeritas Muhammadiyah Yogyakarta \\ I N F O A R T I K E L \\ Kata Kunci: \\ Profitabilitas, Ukuran \\ Perusahaan, Leverage, \\ Afiliasi Politik, Proporsi \\ Dewan Komisaris \\ Independen, dan Carbon \\ Emission Disclosure. \\ Jenis Artikel: \\ Penelitian Empiris \\ Correspondence: \\ hafiez.sofyani@umy.ac.id

\begin{abstract}
A B S TRAK
\end{abstract} \\ Penelitian ini bertujuan untuk menguji pengaruh profitabilitas, ukuran \\ perusahaan, leverage, afiliasi politik dan proporsi dewan komisaris \\ independen terhadap carbon emission disclosure. Sampeldalam \\ penelitian ini adalah seluruh perusahaan pertambanganyang terdaftar di \\ Bursa Efek Indonesia (BEI)periode2014-2016. Dengan menggunakan \\ metodepurposive sampling,didapatkan 64 perusahaan selama tahun 2014- \\ 2016 yang memenuhi kriteria sebagai sampel penelitian. Pengujian yang \\ dilakukan meliputi :statistik deskriptif, asumsi klasik, regresi berganda, \\ koefisien determinasi dan uji T. Berdasarkan hasil uji hipotesis dan analisis \\ yang telah dilakukan maka diperoleh hasil penelitian bahwaukuran \\ perusahaan berpengaruh positif dan leverageberpengaruh negatif terhadap \\ carbon emission disclosure. Sedangkan profitabilitas, afiliasi politik dan \\ proporsi dewan komisaris independen tidak memiliki pengaruh positif \\ terhadap carbon emission disclosure.
}

(C) 2019 RAB. Published by Universitas Muhammadiyah Yogyakarta

\section{PENDAHULUAN}

Perubahan iklim sebagai fenomena global merupakan salah satu isu lingkungan terbesar beberapa tahun terakhir ini. Dampak perubahan iklim adalah meningkatnya suhu di bumi secara global atau sering disebut pemanasan global (global warming). Perubahan iklim terjadi karena gas rumah kaca (GRK) hasil aktivitas manusia terus bertambah di atmosfer bumi. Seperti dikutip dari Intergovernmental Panel on Climate Change atau IPCC (2007) terdapat kenaikan rata-rata suhu permukaan global dengan laju $0,74^{\circ} \mathrm{C} \pm 0,18^{\circ} \mathrm{C}$ di berbagai negara termasuk di Indonesia. Dampak perubahan iklim yang terjadi akhir-akhir ini meliputi kenaikan suhu permukaan, perubahan cuaca hujan, kenaikan suhu dan tinggi air laut, peningkatan iklim dan cuaca ekstrim (Bappenas, 2014).

Menurut Griffiths dkk., (2007) pemanasan global dan risiko perubahan iklim diakui secara internasional sebagai masalah yang signifikan bagi perusahaan. Isu yang berkembang akhir-akhir ini mengenai pemanasan global juga sangat berkaitan dengan aktivitas perusahaan.

Sektor energi yang sebelumnya tidak menjadi sorotan ternyata menyumbang emisi gas rumah kaca besar. Pendataan Kementerian Lingkungan Hidup (KLHK) mengungkap bahwa pada tahun 2013, total emisi karbon dioksida dari energi sebesar 494.998.490 ton. Direktur Inventarisasi Gas Rumah Kaca di sela Seminar Perubahan Iklim bertema "Implementasi di Tingkat Nasional dan 
Persiapan Menuju COP 21 Paris" pada Jumat (3/7/2015) mengungkapkan bahwa emisi paling besar berasal dari batubara dan transportasi (www.sainskompas.com, 2015).

Pengungkapan emisi karbon dikembangkan sebagai perlakuan akuntansi atas isu-isu tersebut, dengan menyajikan pendekatan perusahaan tentang karbon yang dihasilkan dari aktivitas operasional perusahaan di dalam annual report, dan dengan adanya pengungkapan tersebut perusahaan dapat melakukan pencegahan atau cara untuk mengurangi emisi karbon (Pratiwi dan Sari, 2016).

Saat ini perusahaan-perusahaan di dunia secara bertahap mulai mempertimbangkan risiko yang cukup material terkait perubahan iklim, baik dampak langsung secara fisik terhadap bisnis mereka atau melalui kebijakan perubahan iklim yang mengubah pola konsumsi masyarakat (Luo, dkk., 2013). Oleh karena itu, timbul permintaan dari para stakeholder bahwa perusahaan perlu mengungkapkan informasi terkait emisi karbon (carbon emission disclosure) untuk menilai kinerja perusahaan. Pengungkapan karbon perusahaan sering disajikan sebagai bentuk pengungkapan sukarela yang berguna untuk pengambilan keputusan internal dan eksternal (Andrew dan Cortese, 2011). Karena perusahaan yang melakukan pengungkapan karbon akan memberi kemudahan stakeholder dalam mempertimbangkan keputusan tentang keadaan kinerja emisi karbon perusahaan, menekan perusahaan untuk mengurangi emisi karbon, berkontribusi terhadap perdebatan publik tentang kebijakan dan regulasi perubahan iklim (Ennis dkk., 2012). Informasi mengenai emisi karbon dapat kita lihat di dalam annual report atau dalam sustainability report perusahaan.

Fenomena yang terjadi seperti ternyata dari top 100 perusahaan yang terdaftar di Bursa Efek Indonesia, baru 30\% perusahaan yang membuat Sustainability Report (SR). Sedangkan dari tahun 2000 sampai saat ini, baru ada 97 perusahaan yang melakukan reporting melalui Global Report Initiative (GRI). Country Program Manager GRI di Indonesia, Bob Eko Kurniawan menjelaskan bahwa ada desakan dari investor khususnya investor yang dari luar agar perusahaan yang sudah terbuka (listed company) membuat laporan keberlanjutan. Investor luar dijelaskannya sudah mulai terdidik dalam hal keberlanjutan. Dengan membuat laporan keberlanjutan ini, perusahaan akan lebih mudah mendapatkan investor. Reputasinya juga akan lebih baik untuk perusahaan, sehingga investor akan lebih tertarik kepada mereka. Indonesia peringkatnya memang lebih besar dibandingkan South East Asia, Amerika Latin dan Afrika, karena populasi Indonesia cukup banyak dan tingkat korporasinya lebih maju. Namun dibandingkan dengan Eropa dan Amerika, Indonesia masih kalah (www.majalahcsr.id, 30 Oktober 2017).

Dari fenomena tersebut dapat dikatakan bahwa perusahan-perusahaan di Indonesia dalam membuat sustainability report masih rendah dibandingkan Eropa dan Amerika. Alasan pertama mungkin dikarenakan, banyak perusahaan yang belum mengetahui baha laporan keberlanutan diwajibkan dalam undang-undang (Daniri, 2008). Undang-Undang (UU) No. 40 Tahun 2007 tentang Perseroan Terbatas. Pasal 66 ayat (2) butir (c), telah mengatur secara tegas agar perusahaan menyampaikan laporan pelaksanaan tanggungjawab sosial dan lingkungan dalam laporan tahunan. Selain itu pelaporan non keuangan secara umum telah diakomodasi dalam Pernyataan Standar Akuntansi Keuangan (PSAK). PSAK No.1 menyatakan tentang penyajian laporan keuangan dinyatakan bahwa perusahaan dapat pula menyajikan laporan tambahan, khususnya bagi industri di mana lingkungan hidup memegang peranan penting. Untuk itu sudah selayaknya perusahaan melaporkan semua aspek yang mempengaruhi kelangsungan operasi perusahaan kepada masyarakat. Alasan kedua, pembuatan laporan keberlanjutan hanya pemborosan biaya, karena banyak materi yang sama dengan laporan tahunan. Menurut Brammer dan Pavelin (2008) perusahaan yang profitable menyediakan sumberdaya yang cukup untuk membayar biaya pengungkapan lingkungan. Sebaliknya perusahaan yang kurang profitable, menyebabkan perusahaan lebih cenderung berfokus pada pencapaian tujuan keuangan, sehingga membatasi kemampuannya dalam usaha pencegahan dan pengungkapan emisi karbon (Luo, dkk., 2013). 


\section{TINJAUAN LITERATUR DAN PERUMUSAN HIPOTESIS}

Teori legitimasi berfokus pada hubungan antara perusahaan dan masyarakat melalui peraturan yang dibuat oleh pemerintah. Sebagaimana yang telah ditekankan oleh Gray dkk., (1996) bahwa pengungkapan berperan dalam menjembatani perusahaan dengan kelompok masyarakat. Teori stakeholder mengatakan bahwa perusahaan bukanlah entitas yang hanya beroperasi untuk kepentingan sendiri namun harus memberikan manfaat bagi stakeholdemya (pemegang saham, kreditor, konsumen, supplier, pemerintah, masyarakat, analis dan pihak yang lain). Teori sinyal (signaling theory) mengatakan bahwa entitas akan mengungkapkan informasi kredibel dan bertanggung jawab yang positif sebagai tanda akan keberhasilan mereka menjalani usahanya (Luo dan Tang 2014; Rahman dkk., 2014; Bouten dan Hoozee 2013; Luo dkk., 2013). Teori power berhubungan dengan kekuasaan dan kehormatan. Menurut Weber (1947) orang mencari kekuasaan belum tentu karena ingin menjadi kaya raya bisa jadi karena pertimbangan kehormatan.

\section{Pengaruh Profitabilitas terhadap Carbon Emission Disclsoure}

Menurut Luo dkk., (2013) bahwa perusahaan dengan kinerja keuangan baik mempunyai kemampuan secara finansial dalam membuat keputusan terkait lingkungan. Sebaliknya, perusahaan dengan kinerja keuangan kurang baik lebih fokus pada pencapaian tujuan keuangan dan peningkatan kinerja mereka sehingga membatasi kemampuannya dalam upaya pencegahan dan pelaporan emisi karbon. Berdasarkan uraian diatas maka dihipotesiskan sebagai berikut:

\section{$\boldsymbol{H}_{I} \quad$ :Profitabilitas perusahaan berpengaruh positif terhadap Carbon Emission Disclosure.}

\section{Pengaruh Ukuran Perusahaan terhadap Carbon Emission Disclosure}

Perusahaan-perusahaan yang lebih besar diasumsikan menghadapi tekanan besar dari publik, maka mereka akan meningkatkan pengungkapan informasi perusahaan untuk membangun citra sosial yang baik sebagai bagian dari strategi bisnis mereka. Selanjutnya citra sosial yang baik tersebut digunakan oleh perusahaan untuk mendapatkan legitimasi dari masyarakat atau komunitas dimana perusahaan tersebut berada. Berdasarkan pada penjelasan di atas, maka dapat dihipotesiskan sebagai berikut:

$H_{2}$ : Ukuran perusahaan berpengaruh positif terhadap Carbon Emission Disclosure.

\section{Pengaruh Leverage terhadap Carbon Emission Disclosure}

Teori stakeholder mengungkapkan bahwa perusahaan yang memiliki tingkat leverage yang tinggi memliki tanggung jawab yang besar terhadap pihak kreditur yang akan memaksa perusahaan untuk melunasi hutang tersebut dengan sumber dana yang tersedia dibandingkan dengan melakukan pengungkapan emisi karbon yang akan menghasilkan biaya yang lebih besar dan dapat menjadi beban bagi perusahaan (Choi, dkk 2013). Berdasarkan pada penjelasan di atas, maka dapat dihipotesiskan sebagai berikut :

$\mathrm{H}_{3}$ : Leverage berpengaruh negatif terhadap Carbon Emission Disclosure. 


\section{Pengaruh Afiliasi Politik terhadap Carbon Emission Disclosure}

Seseorang yang memiliki peran penting dalam sebuah perusahaan dimana ia juga memiliki hubungan politik maka ia akan menjaga reputasinya sebagai orang yang terpandang dan dikenal oleh banyak orang. Untuk menjaga reputasinya dan memberikan citra yang baik pada masyarakat karena jabatannya sebagai politikus dan juga pimpinan perusahaan ia cenderung akan melakukan pencegahan terhadap masalah yang kelak dapat ditimbulkan perusahaan yang dapat mencoreng reputasinya di dunia politik. Hal ini sejalan dengan teori power yang menyatakan bahwa kekuasaan dan kehormatan memerlukan jaminan dari adanya ketertiban berdasarkan norma dan aturan yang berlaku (Weber, 1947). Berdasarkan pada penjelasan di atas, maka dapat dihipotesiskan sebagai berikut :

\section{$\boldsymbol{H}_{4}$ : Afiliasi politik berpengaruh positif terhadap Carbon Emission Disclosure.}

\section{Pengaruh Proporsi Dewan Komisaris terhadap Carbon Emission Disclosure}

Komisaris independen merupakan pihak yang tidak terafiliasi dengan pihak yang mempunyai hubungan bisnis dan kekeluargaan dengan pemegang saham pengendali, anggota direksi dan dewan domisaris lain, serta dengan perusahaan itu sendiri (KNKG, 2010). Gray, dkk.,(1995) mengatakan bahwa informasi yang diungkapkan kepada stakeholder merupakan legitimasi tanggung jawab sosial dan lingkungan yang telah dilakukan perusahaan. Dewan komisaris independen sebagai pengawas cenderung menyadari bahwa pengungkapan lingkungan dengan sukarela dapat digunakan untuk mempertahankan legitimasi perusahaan. Legitimasi dapat dilihat sebagai suatu yang diinginkan dan dicari perusahaan dari masyarakat (Ghozali dan Chariri, 2007). Berdasarkan pada penjelasan di atas, maka dapat dihipotesiskan sebagai berikut : $\boldsymbol{H}_{s} \quad$ : Proporsi dewan komisaris independen berpengaruh positif terhadap Carbon Emission
Disclosure.

\section{METODE PENELITIAN}

Objek dalam penelitian ini adalah seluruh perusahaan pertambangan yang terdaftar di Bursa Efek Indonesia (BEI) selama periode tahun 2014-2016. Populasi penelitian ini adalah 126 perusahaan pertambangan. Dari jumlah populasi ditentukan sampel sejumlah 64 perusahaan dengan metode purposive sampling.

Kriteria-kriteria yang ditetapkan untuk pengambilan sampel penelitian ini adalah sebagai berikut:

1) Perusahaan sektor pertambangan yang terdaftar di Bursa Efek Indonesia pada tahun 2014-2016.

2) Perusahaan pertambangan yang menyediakan sustainability report atau annual report.

3) Perusahaan yang melakukan pengungkapan emisi karbon (mencakup minimal satu kebijakan yang terkait dengan emisi karbon/gas rumah kaca atau mengungkapkan minimal satu item pengungkapan emisi karbon).

4) Perusahaan yang tidak mengalami kerugian.

Pengukuran indeks Carbon Emission Disclosure diperoleh dengan analisis konten (content analysis), yaitu diberikan skor 0 jika perusahaan tidak mengungkapkan item dari daftar dan diberikan skor 1 jika perusahaan mengungkapkan item pada sustainability report atau annual report. Dalam penelitian ini, profitabilitas diukur dengan menggunakan ROA yang dikembangkan oleh Jannah dan Muid (2014) yaitu membandingkan total laba sebelum pajak dengan total aset. Ukuran perusahaan diukur dengan menggunakan logaritma natural dari total asset yang dikembangkan oleh Jogiyanto Hartono (2013). Leverage diukur dengan menggunakan DER. 
Variabel independen afiliasi politik pada penelitian ini diukur dengan menggunakan variabel dummy dimana nilainya hanya 1 atau 0 (Pranoto dan Widagdo, 2016). Nilai 1 untuk perusahaan yang memenuhi salah satu kriteria sebagai perusahaan yang memiliki afiliasi politik dan nilai 0 jika sebaliknya. Indikator yang digunakan untuk mengukur variabel proporsi dewan komisaris independen yaitu jumlah proporsi komisaris independen dibagi dengan total suluruh komisaris yang dimiliki dalam suatu perusahaan (Nainggolan dan Rohman, 2015).

Pengujian hipotesis dalam penelitian ini dilakukan dengan analisis regresi linier berganda untuk mengetahui seberapa besar pengaruh variabel dependen dengan variabel independen. Uji analisis regresi linier berganda dilakukan karena terdapat lebih dari satu variabel independen dalam penelitian ini. Pengujian hipotesis dapat dituliskan dalam persamaan regresi sebagai berikut:

Carbon_disclosure $=\beta+\beta 1$ Prof $+\beta 2$ Firm_Size $+\beta 3$ DER $+\beta 4$ Afiliasi_Pol $+\beta 5$ DK $+\mathrm{e}$

\begin{tabular}{|c|c|}
\hline Carbon_disclosure & $=$ Carbon Emission Disclosure \\
\hline$\beta$ & $=$ Konstanta \\
\hline$\beta 1-\beta 5$ & $=$ Koefisien Regresi \\
\hline Prof & $=$ Profitabilitas \\
\hline Firm_Size & $=$ Ukuran perusahaan \\
\hline DER & $=$ Leverage \\
\hline Afiliasi_Pol & $=$ Afiliasi politik \\
\hline DK & $=$ Proporsi dewan komisaris \\
\hline
\end{tabular}

\section{HASIL DAN PEMBAHASAN}

Berdasarkan tabel statistik deskriptif di atas, menunjukkan bahwa jumlah sampel penelitian ini adalah 64 perusahaan. Variabel profitabilitas memiliki nilai rata-rata 0,0665 atau 6,65\% dan standar deviasi sebesar 0,09984 atau 9,984\%. Variabel ukuran perusahaan memiliki nilai rata-rata 29,5728 dan standar deviasi sebesar 1,34037. Variabel leverage memiliki nilai rata-rata 0,4613 dan standar deviasi sebesar 0,25819. Variabel afiliasi politik memiliki nilai rata-rata sebesar 0,7188 dan standar deviasi sebesar 0,45316. Variabel proporsi dewan komisaris independen memiliki nilai ratarata 0,3706 dan standar deviasi sebesar 0,10647 .

Tabel 1 Hasil Statistik Deskriptif

\begin{tabular}{llllll}
\hline Model & N & Minimum & Maximum & Mean & Std. Deviation \\
\hline Prof & 64 & 0,001 & 0,689 & 0,0665 & 0,09984 \\
Firm_size & 64 & 26,623 & 32,723 & 29,5728 & 1,34037 \\
DER & 64 & 0,140 & 1,898 & 0,4613 & 0,25819 \\
Afiliasi_pol & 64 & 0,000 & 1,000 & 0,7188 & 0,45316 \\
DK & 64 & 0,000 & 0,667 & 0,3706 & 0,10647 \\
Carbon_disclosure & 64 & 0,056 & 1,000 & 0,2882 & 0,30634 \\
Valid N (listwise) & 64 & & & & \\
\hline
\end{tabular}

Variabel carbon emission disclosure memiliki nilai rata-rata sebesar 0,2882 dan standar deviasi sebesar 0,30634. Nilai minimum variabel carbon emission disclosure sebesar 0,056 atau $5,6 \%$ yang dimiliki oleh beberapa perusahaan, ini berarti bahwa perusahaan dalam mengungkapkan carbon emission disclosure sebesar 5, 6\%. Sedangkan nilai maksimum carbon emission disclosure yaitu sebesar 1,00 atau 100\% dimiliki oleh dua perusahaan yaitu PT Bukit Asam Tbk (PTBA) dan PT Vale Indonesia Tbk (INCO), yang artinya bahwa perusahaan dalam mengungkapkan carbon emission disclosure sebesar $100 \%$ atau seluruhnya. 


\section{Uji Asumsi Klasik}

Uji asumsi klasik yang akan diujikan persamaan dalam penelitian ini adalah uji normalitas, uji multikolinieritas, dan uji heteroskedastisitas.

\section{Uji Normalitas}

Tabel 2 Hasil Uji Normalitas, One-Sample Kolmogorov-Smirnov Test

\begin{tabular}{lr}
\hline & Unstandardized Residual \\
\hline N & 64 \\
Kolmogorov-Smirnov Z & 0,863 \\
Asymp. Sig (2-tailed) & 0,445 \\
\hline
\end{tabular}

Berdasarkan tabel 2 di atas, hasil uji normalitas diatas memperlihatkan nilai Asymp. Sig (2tailed) sebesar 0,445> $\alpha$ 0,05. Nilai Asymp. Sig (2-tailed) lebih besar dari nilai $\alpha$ yaitu 0,05 yang berarti dapat disimpulkan bahwa pada penelitian ini data berdistribusi normal.

\section{Uji Multikolinearitas}

Tabel 3 Hasil Uji Multikolinearitas

\begin{tabular}{lccl}
\hline \multicolumn{1}{c}{ Variabel } & Tolerance & VIF & Kesimpulan \\
\hline Prof & 0,898 & 1,114 & Tidak terjadi multikolinearitas \\
Firm_size & 0,853 & 1,173 & Tidak terjadi multikolinearitas \\
DER & 0,924 & 1,083 & Tidak terjadi multikolinearitas \\
Afiliasi_pol & 0,840 & 1,191 & Tidak terjadi multikolinearitas \\
DK & 0,902 & 1,109 & Tidak terjadi multikolinearitas \\
\hline
\end{tabular}

Berdasarkan hasil dari tabel di atas, terlihat bahwa ke lima variabel memiliki tolerance lebih dari 0,10 dan nilai VIF kurang dari 10. Dari hasil uji multikolinearitas pada tabel 4.4, dapat disimpulkan bahwa model regresi tersebut dinyatakan bebas dari multikolinearitas.

\section{Uji Heterokedastisitas}

Tabel 4 Hasil Uji Heterokedastisitas

\begin{tabular}{lcc}
\hline \multicolumn{1}{c}{ Variabel } & Sig & Kesimpulan \\
\hline Prof & 0,714 & Tidak terjadi heterokedastisitas \\
Firm_size & 0,891 & Tidak terjadi heterokedastisitas \\
DER & 0,482 & Tidak terjadi heterokedastisitas \\
Afiliasi_pol & 0,850 & Tidak terjadi heterokedastisitas \\
DK & 0,290 & Tidak terjadi heterokedastisitas \\
\hline
\end{tabular}

Asumsi bahwa tidak terjadi heterokedastisitas adalah apabila nilai sig > 0,05. Dari hasil yang didapatkan pada table diatas terlihat bahwa masing-masing variabel mendapatkan nilai signifikan lebih besar dari 0,05. Dengan demikian dapat disimpulkan bahwa model regresi pada penelitian ini datanya tidak terjdi heterokedastisitas

\section{Uji Autokorelasi}

Tabel 5 Hasil Uji Autokorelasi

\begin{tabular}{cccc}
\hline Model & N & Durbin Watson & Kesimpulan \\
\hline 1 & 64 & 2,364 & Bebas dari autokorelasi \\
\hline
\end{tabular}

Dari tabel diatas yang didapatkan dari uji autokorelasi nilai Durbin Watson adalah sebesar 2,364 dengan jumlah $\mathrm{n}=64$, jumlah variabel bebas $\mathrm{k}=5$ sehingga ditentukan perolehan nilai $\mathrm{d} \mathrm{U}$ 
sebesar 1,7672 dan nilai 4-dl sebesar 1,4322 pada tabel Durbin Watson. Berdasarkan kriteria yang telah ditentukan DW hitung berada diantara 1,7672 dan 2,5678, yakni 1,7672 $\leq 2,364 \leq 2,5678$ yang menunjukkan bahwa data pada penelitian tidak terjadi autokorelasi.

\section{Pengujian Hipotesis}

\section{Uji Koefisien Determinasi}

Tabel 6 Hasil Uji Koefisien Determinasi

\begin{tabular}{cccccc}
\hline Model & R & R Square & $\begin{array}{c}\text { Model Summary }^{\mathrm{b}} \\
\text { Adjusted R Square }\end{array}$ & $\begin{array}{c}\text { Std. Error of the } \\
\text { Estimate }\end{array}$ & Durbin-Watson \\
\hline 1 & $0,777^{\mathrm{a}}$ & 0,604 & 0,570 & 0,20093 & 2,364 \\
\hline
\end{tabular}

Besarnya Adjusted $R$ Square pada tabel adalah 0,570. Hasil tersebut menunjukkan bahwa variabel independen yang terdiri dari profitabilitas, ukuran perusahaan, leverage, afiliasi politik, dan proporsi dewan komisaris dalam menjelaskan variabel dependen yaitu carbon emission disclosure adalah sebesar 0,570 atau 57\% sedangkan sisanya sebesar 43\% (100\%-57\%) dijelaskan oleh faktor lain diluar model penelitian.

\section{Uji Statistik T (Uji T)}

Tabel 7 Hasil Uji T

\begin{tabular}{lrrrl}
\hline \multicolumn{1}{c}{ Variabel } & B & T & Sig. & Kesimpulan \\
\hline (Constant) & $-3,091$ & $-5,033$ & 0,000 & \\
Profitabilitas & 0,017 & 0,065 & 0,948 & Tidak Berpengaruh \\
Ukuran perusahaan & 0,137 & 6,721 & 0,000 & Berpengaruh \\
Leverage & $-0,523$ & $-5,128$ & 0,000 & Berpengaruh \\
Afiliasi Politik & $-0,071$ & $-1,165$ & 0,249 & Tidak Berpengaruh \\
Dewan komisaris & $-1,067$ & $-4,263$ & 0,000 & Berpengaruh \\
\hline
\end{tabular}

Berdasarkan tabel 4.9, hasil pengujian untuk mengetahui hipotesis penelitian adalah sebagai berikut:

a. Pengujian hipotesis 1

Hipotesis pertama menyatakan bahwa profitabilitas berpengaruh positif terhadap carbon emission disclosure. Berdasarkan tabel 4.9., hasil uji-t menunjukkan bahwa untuk variabel profitabilitas memiliki nilai koefisien regresi positif sebesar 0,017 dan nilai signifikansi sebesar 0,948>0,05 yang artinya profitabilitas tidak berpengaruh terhadap carbon emission disclosure.

b. Pengujian hipotesis 2

Hipotesis kedua menyatakan bahwa ukuran perusahaan berpengaruh positif terhadap carbon emission disclosure. Berdasarkan tabel 4.9., hasil uji- $t$ menunjukkan bahwa untuk variabel ukuran perusahaan memiliki nilai koefisien regresi positif sebesar 0,137 dan nilai signifikansi sebesar $0,000>0,05$ yang artinya ukuran perusahaan memiliki pengaruh positif terhadap carbon emission disclosure.

c. Pengujian hipotesis 3

Hipotesis ketiga menyatakan bahwa leverage berpengaruh negatif terhadap carbon emission disclosure. Berdasarkan tabel 4.9., hasil uji $t$ menunjukkan bahwa untuk variabel leverage memiliki nilai koefisien regresi negatif sebesar -0,523 dan nilai signifikansi sebesar 0,000 $<0,05$ yang artinya leverage berpengaruh negatif terhadap carbon emission disclosure.

d. Pengujian hipotesis 4 
Hipotesis keempat menyatakan bahwa afiliasi politik berpengaruh positif terhadap carbon emission disclosure. Berdasarkan tabel 4.9., hasil uji tmenunjukkan bahwa untuk variabel afiliasi politik memiliki nilai koefisien regresi negatif sebesar -0,071 dan nilai signifikansi sebesar 0,249 $>0,05$ yang berarti bahwa afiiasi politik tidak berpengaruh terhadap carbon emission disclosure.

e. Pengujian hipotesis 5

Hipotesis kelima menyatakan bahwa proporsi dewan komisaris independen berpengaruh positif terhadap carbon emission disclosure. Berdasarkan tabel 4.9., hasil uji $t$ menunjukkan bahwa untuk variabel proporsi dewan komisaris independen memiliki nilai koefisien regresi negatif sebesar -1,067 dan nilai signifikansi sebesar $0,000<0,05$ yang berarti bahwa proporsi dewan komisaris independen berpengaruh negatif terhadap carbon emission disclosure.

\section{Pembahasan}

1. Pengaruh Profitabilitas terhadap Carbon Emission Disclsoure

Hasil yang didapatkan dalam penelitian untuk hipotesis pertama adalah profitabilitas tidak berpengaruh terhadap carbon emission disclosure (H1 tidak terdukung atau ditolak). Ada kemungkinan profitabilitas yang diproksi dengan ROA tidak berpengaruh terhadap pengungkapan carbon emission disclosure dikarenakan perusahaan dengan profitabilitas yang tinggi akan lebih fokus pada kesuksesan pencapaian laba perusahaan yang diperoleh (Purnasiwi, 2011). Sehingga cenderung akan mengabaikan tentang pelaporan informasi sukarela yang khususnya berkaitan dengan lingkungan. Purnasiwi (2011) juga menyatakan bahwa perusahaan dengan profitabilitas yang rendah justru akan mempertahankan reputasi perusahaan dengan mengungkapkan informasi sukarela tentang lingkungan. Hal tersebut dilakukan oleh perusahaan untuk meningkatkan nilai perusahaan, sehingga disaat kinerja keuangan perusahaan kurang baik, perusahaan akan tetap memperoleh dukungan dari stakeholder.

\section{Pengaruh Ukuran Perusahaan terhadap Carbon Emission Disclsoure}

Hasil yang didapatkan dalam penelitian untuk hipotesis kedua adalah ukuran perusahaan berpengaruh positif terhadap carbon emission disclosure (H2 terdukung atau diterima). Terdapat penyebab yang mungkin menjadikan ukuran perusahan berpengaruh positif terhadap carbon emission disclosure. Ukuran perusahaan yang dilihat melalui total asetnya menunjukkan seberapa besar harta kekayaan yang dimiliki perusahaan. Semakin besar ukuran perusahaan, memudahkan perusahaan untuk menutupi biaya pelaporan sukarela dan menghasilkan sumber daya manusia (SDM) yang unggul serta memiliki kapabilitas dalam melakukan carbon emission disclosure. Hal tersebut dilakukan perusahaan untuk mempertahankan image-nya, walaupun perusahaan harus mengorbankan sumber daya demi aktivitas tersebut (Gunawan dan Utami, 2008).

\section{Pengaruh Leverage terhadap Carbon Emission Disclsoure}

Hasil yang didapatkan dalam penelitian untuk hipotesis ketiga adalah leverage berpengaruh negatif terhadap carbon emission disclosure $\left(\mathrm{H}_{3}\right.$ terdukung atau diterima). Perusahaan yang melakukan pengungkapan lingkungan dengan kondisi keuangan yang buruk akan menyebabkan kekhawatiran bagi debt holders, suppliers, dan pelanggan (Choi, dkk 2013). Perusahaan dengan leverage yang tinggi akan lebih berhati-hati dalam mengurangi dan mengungkapkannya terutama menyangkut mengenai pengeluaran- pengeluaran yang berkaitan dengan pengungkapan dan tindakan pencegahan emisi karbon (Luo dkk, 2013). Hal tersebut dikarenakan melakukan pengungkapan sukarela seperti pengungkapan lingkungan dianggap sebagai extra cost bagi perusahaan.

4. Pengaruh Afiliasi Politik terhadap Carbon Emission Disclsoure

Hasil yang didapatkan dalam penelitian untuk hipotesis keempat adalah afiliasi politik tidak berpengaruh terhadap carbon emission disclosure ( $\mathrm{H}_{4}$ tidak terdukung atau ditolak). 
Berdasarkan hasil penelitian ini, dapat disimpulkan bahwa adanya afiliasi politik dalam suatu perusahaan tidak mempengaruhi carbon emission disclosure. Hal ini terjadi mungkin dikarenakan pimpinan perusahaan yang memiliki afiliasi politik atau rangkap jabatan tidak terlalu memperhatikan praktik pengungkapan lingkungan perusahaan (seperti carbon emission disclosure) karena kesibukannya yang memiliki rangkap jabatan. Selain itu mungkin karena pimpinan perusahaan yang berafiliasi politik kurang efektif dibandingkan pimpinan perusahaan yang tidak berafiliasi politik, karena pimpinan perusahaan yang berafiliasi politik akan lebih sulit dalam menjalankan perannya yang memiliki rangkap jabatan, seperti kesulitan dalam mengawasi dan mengkoordinir tindakan manajemen dalam pengungkapan lingkungan seperti carbon emission disclosure.

5. Pengaruh Proporsi Dewan Komisaris Independen terhadap Carbon Emission Disclsoure

Hasil yang didapatkan dalam penelitian untuk hipotesis kelima adalah proporsi dewan komisaris independen berpengaruh negatif terhadap carbon emission disclosure $\left(\mathrm{H}_{5}\right.$ tidak terdukung atau ditolak). Proporsi dewan komisaris independen tidak dapat meningkatkan fungsi pengawasan dan pengungkapan laporan keberlanjutan mungkin dikarenakan dewan komisaris independen yang jumlahnya besar kurang efektif dibandingkan dewan komisaris independen yang jumlahnya lebih kecil. Ini menunjukkan bahwa makin banyak anggota dewan komisaris maka badan akan mengalami kesulitan dalam menjalankan perannya, diantaranya seperti kesulitan berkomunikasi dan mengkoordinir kerja dari masing-masing anggota dewan komisaris independen itu sendiri, kesulitan dalam mengawasi dan mengendalikan tindakan manajemen termasuk dalam pengungkapan lingkungan seperti carbon emission disclosure.

\section{KETERBATASAN PENELITIAN}

Dalam melakukan penelitian, peneliti menyadari masih banyak keterbatasan yang dihadapi, yaitu penelitian hanya menggunakan satu sektor perusahaan saja sehingga hasil penelitian kurang relevan apabila dikaitkan untuk semua sektor perusahaan. Periode pengamatan dalam penelitian ini cukup singkat yaitu hanya tiga tahun dari tahun 2014-2016. Subyektif dalam menilai indeks luas pengungkapan, karena akan berbeda dari sudut pandang setiap orang yang akan membacanya. Penelitian ini hanya menggunakan beberapa faktor yaitu profitabilitas, ukuran perusahaan, leverage, afiliasi politik, dan proporsi dewan komisaris sehingga belum mencerminkan secara keseluruhan faktor-faktor yang mempengaruhi carbon emission disclosure.

\section{KESIMPULAN}

Penelitian ini bertujuan untuk menguji dan memperoleh bukti empiris tentang pengaruh profitabilitas, ukuran perusahaan, leverage, afiliasi politik dan proporsi dewan komisaris independen terhadap carbon emission disclosure (studi empiris pada perusahaan pertambangan yang terdaftar di Bursa Efek Indonesia periode 2014-2016). Berdasarkan hasil analisis yang telah dilakukan, dapat disimpulkan profitabilitas tidak berpengaruh terhadap carbon emission disclosure. Ukuran perusahaan berpengaruh positif dan signifikan terhadap carbon emission disclosure. Leverage berpengaruh negatif dan signifikan terhadap carbon emission disclosure. Afiliasi politik tidak berpengaruh terhadap carbon emission disclosure. Proporsi dewan komisaris independen berpengaruh negatif dan signifikan terhadap carbon emission disclosure.

Berdasarkan hasil penelitian dan pembahasan yang telah diuraikan sebelumnya, maka saran bagi penelitian selanjutnya yang dapat diberikan oleh peneliti adalah penelitian selanjutnya sebaiknya menggunakan atau menambah perusahaan sektor lain dalam sampel penelitiannya, sehingga tidak hanya menggunakan perusahaan sektor perusahaan pertambangan saja. Penelitian selanjutnya diharapakan untuk menambah tahun pengamatan, sehingga hasil yang didapatkan dalam penelitian lebih valid dan lebih terkini. Menambahkan variabel-variabel lain yang 
berpengaruh terhadap carbon emission disclosure, seperti kepemilikan institusional, komite audit, regulator, pertumbuhan, dan lain sebagainya.

\section{DAFTAR PUSTAKA}

Bappenas (Badan Perencanaan Pembangunan Nasional). (2014). Rencana Aksi Nasional Adaptasi Perubahan Iklim. Jakarta.

Bouten, L. \& Hoozee, S. (2013). On the Interplay between Environmental Reporting and Management Accounting Change. Management Accounting Research, 24 (4), 333-348.

Choi, dkk. (2013). An analysis of Australian company carbon emission disclosures. Pacific Accounting Review, 25 (1), 58-79.

Ghozali \& Chariri. (2007). Teori Akuntansi. Semarang: Badan Penerbit Undip.

Gray, dkk. (1996). Accounting and Accountability: Changes and Challenges in Corporate Social and Environmental Reporting. Prentice Hall Europe, Hemel Hempstead.

Gray, R., \& Lavers, S. (1995). Constructing a research database of social and environmental reporting by UK companies. Accounting, Auditing, \& Accountability Journal, 19(3), 78-101.

Griffiths, A., Haigh, N. \& Rassias, J. (2007). A framework for understanding institutional governance system and climate change: the case of Australia. European Management Journal,. 25 (6), 415.

Gunawan, B., \& Utami, S. S. (2008). Peranan Corporate Social Responbility dalam Nilai Perusahaan. Jurnal Ilmiah Mahasiswa FEB, 7 (2), 19-32.

IPCC (International Panel on Climate Change). (2007). The Physical Science Basis, Contribution of Working Group I to the Fourth Assessment Report of the Intergovernmental Panel on Climate Change. Diakses pada 29 Oktober 2017.

Jannah, R., \& Muid, D. (2014). Analisis Faktor-faktor yang Mempengaruhi Carbon Emission Disclosure pada Perusahaan di Indonesia (Studi Empiris pada Perusahaan yang Terdaftar di Bursa Efek Indonesia Periode 2010-2012). Jurnal Akuntansi Undip, 3 (2).

Jogiyanto, H. (2013). Teori Portofolio dan Analisis Investasi. BPFE Yogyakarta, Edisi Kedelapan. Yogyakarta.

KNKG. (2010). Pedoman Etika Bisnis Perusahaan. Jakarta: PT. Elex Media Computindo.

Luo, L. \& Tang, Q. (2014). Does Voluntary Carbon Disclosure Reflect Underlying Carbon Performance?. Journal of Contemporary Accounting \& Economics, 10 (3), 191-205.

Luo, L, Qingliang, T., Yi-chen, L. (2013). Comparison of Propensity for Carbon Disclosure between Developing and Developed Countries. Accounting Research Journal. 26 (1), 6-34.

Nainggolan, N. E. \& Rohman, A. (2015). Pengaruh Struktur Corporate Governance Terhadap Pengungkapan Lingkungan (Studi Empiris pada Perusahaan Non-keuangan yang Terdaftar di Bursa Efek Indonesia Periode 2011-2013). Diponegoro Journal of Accounting, 4 (2), 1-9.

Pranoto, B. A., \& Widagdo, A. K. (2016). Pengaruh Koneksi Politik dan Corporate Governance Terhadap Tax Aggressiveness. ISSN 2460-0784, 472-486.

Purnasiwi, J. (2011). Analisis Pengaruh Size, Profitabilitas, dan Leverage Terhadap Pengungkapan CSR pada Perusahaan yang Terdaftar di Bursa Efek Indonesia. Disertasi. Semarang: fakultas Ekonomika dan Bisnis, Universitas Diponegoro.

Rahman, N. R. A, dkk. (2014). Exploring the Relationship between Carbon Performance, Carbon Reporting and Firm Performance: A Conceptual Paper. Procedia Social and Behavioral Sciences, 164, 118-125.

Utomo, Y. W. (2015). Batubara dan Transportasi Penyumbang Emisi Terbesar Sektor Energi. https://sains.kompas.com/read/2015/07/03/19453981/Batubara.dan.Transportasi.Penyumb ang.Emisi.Terbesar.Sektor.Energi. Diakses pada tanggal 13 Agustus 2018, pukul 16.43 WIB.

Weber, M. (1947). The Theory of Social and Economic Organization. Ed. Parsons, Talcott. New York: Oxford University Press. 